\title{
A Share of VAT on GDP in Nepal After 2010 A.D
}

\author{
Krishna Gopal Adhikari ${ }^{1}$
}

\begin{abstract}
This research paper examines the share of VAT on GDP in Nepal After 2010 A.D. Value Added Tax (VAT) is the most recent innovation in the field of taxation. Actually, VAT is considered one of the most important tax revenue of the second half of the twentieth century. It is a scientific tax system, which was first introduced in 1954 in France. VAT is a family member of indirect tax. Economic development has been one of the most popular slogans in almost all the developing countries all over the world. The main concern of study is to analyze the share of VAT on the gross domestic product in Nepal. This article based up secondary source of information collects from economic survey, books, article, journals and research paper. This paper employs descriptive research design. This study shows that the share of VAT is increasing every year since 2010 A.D. It plays the important role for economic development in Nepal. This article is very useful to the researchers, government and policy makers who want to know the contribution of VAT on GDP in Nepal. VAT is a broad based tax as it also covers the value added to each commodity by a firm during all stages of production and distribution.
\end{abstract}

Keyword: Income tax, tax revenue, indirect tax, VAT, GDP.

\section{Introduction}

Value added tax (VAT) is the major source of government revenue. The role of revenue in the development of a country is not less important than the role of oxygen for the existence of human body. The revenue collection is a challenging task in itself which demands increasing necessity of regular expenditure in general and development expenditure in particular. The government can collect revenue from taxable and non taxable sources. Tax is a key source for revenue generation and mobilization. The taxpayer does not have any right to receive the direct benefit from the tax paid. A tax is not a price paid by one for which he can claim for goods and services.

Taxes are major fiscal policy instruments and important government policy tools have an important role in increasing the rate of capital formation and there by a high rate of economic growth can be achieved. On the other hand, taxation may be used to promote useful investment in the private sector and to use resource mobilization. So, Taxation may be utilized by the

\footnotetext{
1 Lecturer (Economics), Pindeshwar Viddhyapith, Dharan, Nepal Sanskrit University, Nepal. Email: krishnagopaladhikari@gmail.com
} 
government as an effective tool for giving incentive to the proper growth of saving, investment and gross domestic product.

But, in Nepal the tax policy is mostly guided towards the revenue generation. The economic status of Nepal is very poor. Nepal has deficit budget and it has been making economic condition of the country very bad. The Government of Nepal is trying to raise the living standard of people conducting various economic development activities. Every government has to spend a lot of money to fulfill its responsibility towards the people to carry out development activity to handle day to day administrative work, to maintain peace and security and to launch other public welfare activities. Tax is one of the major sources of revenue collections. It is a compulsory levy imposed by government the people and institution of the country according to the prevailing laws. Income tax can be defined as the contribution from people and business organization to the government from their income either by service or from business without taking the corresponding or direct benefit. A tax imposed on income base is called income tax. Generally tax can be classified into two types. They are: (a) Direct tax, and (b) Indirect tax. Direct tax which is directly paid by a person and it is legally imposed. Some of the direct taxes are income tax, property tax, health tax and the vehicle tax. Indirect tax is tax which is imposed on one person and paid partly or fully by another. Some of indirect taxes are sales tax, entertainment tax, hotel tax, passenger tax, import or excise duty and value added tax (VAT), etc are indirect tax.

VAT is probably the best tax system and the most important innovation of the second half of the twentieth century, which is considered as an effective means to collect revenue as a reformed sales tax of indirect tax system. It is a modern tax system which enables to efficient collection system, to increase efficiency and to reduce tax evasion. It is also refereed as the backbone of income tax system in Nepal. VAT plays great role in the revenue mobilization in Nepal. The reason behind VAT system, it makes transparency in all kinds of transaction, helps to make the wide area of tax and discourages tax evasion. So it is needless to say that VAT is the most important sources of the government revenue. VAT is intended to be levied or charged whenever there is some value addition to raw material. The taxpayers on the other hand, will get credit for the amount of tax paid off at the stages of procurement. The value added tax system has proven to be effective in avoiding problems that normally might arise out of the double taxation of goods and services. The lesson learnt of tax reforms in developing countries proves that VAT is the most important choice and ingredient of tax reform. It may be adopted by a developing country with no difficulty and is an important instrument for the mobilization of resources.

\section{VAT: An Historical Perspective}

VAT is the most scientific system of sales tax. In the early days, the tax from the consumption and production is collected as sales tax. But now, it is almost completely replaced 
by the VAT. The concept of VAT was introduced in 1919 by Dr. Wilhem Von Sieman in Germany. This concept was brought to replace the " Usnatzsterller" (multi stage sales tax) due to its undesirable effects, particularly cascading and vertical integration of the latter tax (MST) for the first time. The Germany knew the administrative complication of the VAT system. So, it has the fear to implement. Therefore, the rate of multi stage tax is reduced instead of the implementation of VAT. In 1921, the America was implementing the corporate income tax. Thomas S Admas suggested the tax for the United State of America to replace the existing tax system. France was the first implementer of VAT in 1954 covering only in the industrial sector. The VAT was limited to only up to whole level. But these countries limited the VAT only on import and manufacturing stage. In late 60 s, VAT started to become popular. Countries like Denmark and Brazil adopted this system of tax in 1967. France, the first implementer of VAT, extended it to the retail level for the first time. And Germany also adopted VAT in the same year. In 1969, the countries like Netherlands and Sweden also adopted VAT in their countries. In 1970, 1971 and 1973, Luxembourg, Belgium and Ireland introduced the VAT respectively. In Asia, Vietnam was the first country to introduce this most scientific tax system. The country adopted VAT in 1973. The trend being VAT popular was increasing all over the world. In 1977, 1984, 1985, 1986, South Korea, China, Indonesia and Taiwan introduced VAT respectively. Similarly, VAT was introduced by Philippine in 1988, Japan in 1989, Thailand in 1992 and Singapore in 1994. In SAARC region, Pakistan was the first adaptor of VAT. It implemented VAT in 1990. India introduced VAT first as modified value added tax (MOD VAT) in 1996. But actually in India, VAT replaced sales tax on 4 January 2005. Though some state did not adopt for VAT (for political reasons), majority of the state embraced VAT, states like Andhra Pradesh and Maharastra taking the lead. The Empowered Committee 21 constituted by Government of India, provided the basic framework for uniform VAT laws in the states but due to the federal nature of Indian constitution, States do have a liberty to set their own valuations for the VAT levied in their own territory. India introduced the full VAT in some prescribed regions of the country on April 1, 2005. Around 130 countries have introduced VAT system across the world.

The Nepalese government revealed its intention for the adoption of various reform programs to promote market oriented economy in the Eighth Plan (1990-1995) document. In a process to reform task policy, it has mentioned that some time in the mid-plan period a VAT will be introduced in the country. Before that VAT was completely unknown word to the general people of Nepal. After a restoration of democracy in 1992/93, a two-tier sales tax system was in function at that period Under this system dealers and distribution of nineselected items were required to register for sales tax purpose and collect tax on their sales. The VAT Act was passed in 1996 by the parliament. The government in 1997 approved VAT Regulations. In the same year, the department of sales Tax and Excise were renamed as the Department of Value Added Tax (VAT). The government was planned to register the potential taxpayer in VAT from this period. In support of VAT, the government decided to rationalize 
the tax structure by educating the rate of income tax, sales tax and custom duties in advance. The VAT was to replace the Hotel Tax, the entertainment Tax and the Contract Tax.

Value Added Tax is not an additional tax, but has replaced taxes such as sales tax, hotel tax, contract tax and entertainment tax that used to be levied on the sale of goods and services. (Khadka, 1997: 11)

VAT was introduced in Nepal in response to realization that a fundamental change was necessary in the country's revenue policy. The business community was strongly against the VAT in the beginning but the gradually withdrew the opposition as they went on being clearer about positive aspects of the VAT and also its simplicity. Government went through many negotiations with business communities before implementing VAT in the Kingdom of Nepal. Taxpayers were opposed to VAT not because of any defect in VAT as a system. Rather they were afraid of frequent contacts with revenue officials who were historically notorious for a behavior that exploited the taxpayers (Jyoti, 2000)

\subsection{Statement of the Problem}

Taxes contribute a significant amount in the public revenues. The government mobilizes its revenues through budget in development activities for the public welfare and interests. Share of VAT on GDP is collected from economic survey of Nepal. It is based up on related literature reviewed, the following research questions are identified.

- How can VAT be made the backbone of Nepalese tax system?

- What is the share of VAT on GDP of Nepal?

\subsection{Objectives of the Study}

The main objective of this study is to analyze the present share of VAT on tax of Nepal. The Specific objective of research is;

- To identify the contribution of VAT on Tax revenue of Nepal.

- To explain the share of VAT on GDP of Nepal.

\subsection{Limitations of the Research Paper}

The research paper has been written within the boundaries of the following limitations:

- Since the study is based on Secondary data, the results depend up on the reliability and validity of data.

- The coverage of the period is from FY 2068/2069 to FY 2072/73 B.S. 


\subsection{Rationale of the Study}

The Rationale of the study attempts to call government and policy makers to solve and frequent change in income tax act and aware people about income tax and encourage them to pay tax. Income tax is a major component of tax revenue and it will also helpful to make equitable society by equitable distribution of wealth.

\subsection{Review of Literature}

A review of literature helps the researcher to develop a thorough understanding and insight into previous research work that relates to the present study.

The implementation of VAT in Nepal would have very poor results than expected due to poor planning and poor implementation. But, VAT implementation has been becoming more and more effective - it has been spreading and revenue collection is on the constant rise establishing it firmly in Nepal. It is expected that positive impact can be seen in tax collection as code of conduct announced recently includes all the required ingredients, such as, utilization of tax revenue, respecting the taxpayers, simplification in the service and improvement in the behavior of the tax administrators. Moreover, he recommended that tax related newspapers, pamphlets, radio, and television tec. Interview programs with professors, researchers, tax experts, and economists should be conducted and published through advertising media. Similarly the students at school campus level curriculum should include tax education and social obligation of paying tax. Border should be effectively controlled to prevent the illegal trade. There should be a broader tax adjustment checking and highway checking should be practical effectively to prevent any kind of illegal trade. The accounting should be transparent and VAT officers should control auditing as far as possible (Basnet, 2002).

Nepal's overall tax structure for the period 1990/91 to 2001/2002, examining the theoretical background of VAT, analyzing the existing VAT system of Nepal with special emphasis on revenue mobilization and identifying the major problems of VAT in Nepal. It study is also chiefly based on the secondary sources and the research design descriptive in nature with the use of figures, ratios, percentages, tables and graphs whenever and wherever necessary. He also concluded that the implementation of VAT system has a greater significance in Nepal. However he comments that the VAT system in Nepal from its inception has been facing innumerable problems, which curtail its merits and effectives (Dhaka,2004).

VAT in order to control the leakage of revenue and to control tax evasion so that the number of the taxpayers would increase and hence the revenue collection would also increase exponentially. He complains that in Nepal, after the implementation of VAT, the government has hardly paid any attention to the consumers. He gave several reasons behind this. According to him, after the implementation of VAT, attempt was made to inform the public about some non-VAT including commodities through the public means of communications like radio, 
television and newspapers, but it could not prove effective. As a result, the consumers are on the other hand, as he argues, the businessmen opposing the VAT had raised the prices of daily consumption goods like rice, vegetable etc, which had added future burden to the consumers (Neupane, 2006).

The present study evaluates the VAT to GDP ratio, which ranges from 2.8 percent in FY 2000/01 to 16.01 percent in FY 2014/15. This ratio has been increasing from FY 2000/01 to FY 2014/15. Similarly, VAT to total tax ratio fluctuates from 30.69 percent to 37.63 percent. Likewise, VAT to indirect tax ratio oscillates from 39.94 percent to 50.05 percent. This study also estimates the average value and growing rate of value added tax during 15 years. It has been estimated through the analysis of time series data for 15 years from FY 2000/01 to FY 2014/15. It is obvious that the annual growing rate of value added tax has been estimated to be Rs. 6.63 billion during the study period. This exhibits that VAT is increasing by Rs. 6.63 billion per year. The increasing trend of VAT exhibits that revenue from VAT to government revenue of Nepal is increasing continuously during the study period (Sutihara, 2016).

In Nepal, budget of 1996/97 announced that VAT would be implemented from November 16, 1997 (Mangsir 1st, 2056). However, full-fledged VAT was effectively acted from August 17, 1999 (Bhadra 1st, 2056). Value Added Tax Act has already been enacted in 1996 to regulate actual practice of VAT. According to Value Added Tax Act 1996, the tax rate is 10 percent and exports are subject to a rate of zero percent. There is provision of threshold and exemption in VAT Act 1996. Now the single rate of VAT is 13 percent (IRD, 1996; 36). VAT in Nepal has replaced existing sales tax and other small service based taxes (hotel tax, entertainment tax, contract tax, etc.) have been incorporated. Obviously, the VAT has broadleaved the tax base and increased the revenue elasticity since the FY 1996/97. At the time of introduction, there were only 2,045 taxpayers converted into VAT from the sales tax revenue, but by the end of 2010/11, registration toll has reached to almost 97,664, registering a phenomenon annual growth of 126.42 percent (Koirala, 2011: 65).

VAT regime is extremely challenging in a burgeoning economy like Nepal where, with long open border, a large segment of the economy is yet to be monetized. Resistance from the business community, ignorance of general people and the lack of full support and commitment from the politicians and government officials forced the authority responsible for implementation VAT to make comparable on various aspects of VAT which has weakened the process of implementation right from the beginning.

\section{Method and Materials}

This research is both qualitative and quantitative in nature. Secondary data have been used in this study. The secondary data have been obtained through economic survey, budget speech, journals and newspaper.

\subsection{Research Design}


This research has been analytical and descriptive in design using historical data to analyze VAT on GDP in Nepalese economy.

\subsection{Population and Sampling}

This study is based on descriptive method using secondary data. To assess the structure of income tax, the data from FY 2068/2069 to FY 2072/73 B.S. have taken into consideration.

\subsection{Source and Types of Data}

This research article is both qualitative and quantitative in nature. It is based on secondary data collected from website of Ministry of finance for the period of eight year from FY 2068/2069 to FY 2072/73 B.S. The information obtained through economic survey, official website of Inland Revenue Department (www.ird.gov.np), related text books and reference books of income tax and public finance. This is presented and analyzed in systematic way.

\subsection{Tools and Techniques}

In order to analyze the research study, different statistical table, diagrams, graphs, trend line, etc. have been used.

\section{Results and Discussions}

This chapter deals with the analysis with the contribution of VAT on GDP in Nepal. The analysis of data is carried out by different figures, tables and charts. In this chapter the data and information which connected with the taxation in Nepal are presented and analyzed which are already published and trying to find out the trend and its contribution of income to GDP.

\subsection{Contribution of VAT in tax revenue of Nepal}

VAT is levied on both domestically produced goods and services and imported goods and services. Nepalese economy is agricultural based. More than $65 \%$ people are farmer and the farming is unorganized sector. Agriculture production through unorganized sector is exempted from VAT. Most of the products and services are imported from neighboring countries and third countries. Thus import generates more VAT revenue than domestically produced goods and services. The compositions of VAT revenue in total tax revenue are shown in a table.

Table 1: Composition of VAT on tax Revenue (Rs. in million)

\begin{tabular}{lllc}
\hline Fiscal year & Total tax revenue & VAT & VAT \% on Total Tax Revenue \\
\hline $2068 / 69$ & $211721 / 80$ & $70930 / 40$ & 33.50 \\
$2069 / 70$ & $259214 / 90$ & $83418 / 40$ & 32.18 \\
$2070 / 71$ & $312441 / 30$ & $101104 / 60$ & 32.35 \\
$2071 / 72$ & $355955 / 70$ & $112521 / 80$ & 31.61 \\
$2072 / 73$ & $421096 / 60$ & $122411 / 90$ & 29.06 \\
\hline
\end{tabular}

Sources: Economic Survey, (2068/69 to 2072/73), MOF 
Above table reveals that share of VAT revenue in total VAT revenue is $33.50 \%$ in an average through the analysis period. The contribution made through VAT in tax revenue is one third. In fiscal year 2068/69, total amount Rs. 70930 million was collected as VAT which was only $33.50 \%$ of Total tax revenue. However, though insignificantly, the percentage shows the decreasing trend, but very low percentage of Total Tax Revenue throughout all the years of analysis. The lowest percentage i.e. $29.06 \%$ was recorded in the fiscal year 2072/73 with VAT revenue amounting to 122411.9. So it can be said that the trend does show a decreasing trend although in a snail pace which can be better seen in the figure 1 . So in conclusion, the contribution made through VAT in Total Tax Revenue is almost one third.

\subsection{Share of VAT Revenue to Gross Domestic Product (GDP)}

Gross Domestic Product is the total final output of goods and services produced by the country's territory by residents and non-residents, regardless of its collection between domestic and foreign claims. The VAT/GDP ratio measures the consistency of the growth of VAT revenue with the corresponding growth in gross National Product. This is an indicator of the utilization of taxable capacity. Normally, the growth of VAT revenue mobilization in line with the growth in GDP is desirable for the rapid economic development of a country. The collection of VAT revenue is more reliable than the Direct tax revenue, Non tax revenue which facilitates the process of economic planning and development in the country. VAT has been introduced in Nepal to increase the contribution towards revenue generation. The contribution of VAT revenue in GDP is shown below.

Table 2: VAT Revenue as percentage of GDP (Rs. in million)

\begin{tabular}{lllc}
\hline Fiscal year & GDP & VAT & VAT Revenue \% of GDP \\
\hline $2068 / 69$ & 670279 & 70930.40 & 10.58 \\
$2069 / 70$ & 697954 & 83418.40 & 11.95 \\
$2070 / 71$ & 739754 & 101104.60 & 13.66 \\
$2071 / 72$ & 764336 & 112521.80 & 14.72 \\
$2072 / 73$ & 767492 & 122411.90 & 15.94
\end{tabular}

Sources: Economic Survey, (2068/69 to 2072/73), MOF

Above table reveals that share of VAT revenue in GDP is $13.37 \%$ in an average through the analysis period. In fiscal year 2068/2009, total amount Rs. 70930.4 million was collected as VAT which was only $10.58 \%$ of GDP. However, though insignificantly, the percentage shows the increasing trend, but very low percentage of GDP throughout all the years of analysis. The highest percentage i.e. 15.95\% was recorded in the fiscal year 2072/2073 with VAT revenue amounting to 122411.90 . So, it can be said that the trend does show an increasing 
trend although in a snail pace which can be better seen in the graph. So in conclusion, the contribution made through VAT in GDP is average $13 \%$.

\subsection{Contribution to VAT on GDP}

VAT is the main source of total revenue. It includes Tax revenue and non-tax revenue. Contribution of VAT on Gross Domestic Product has been shown in figure 1.

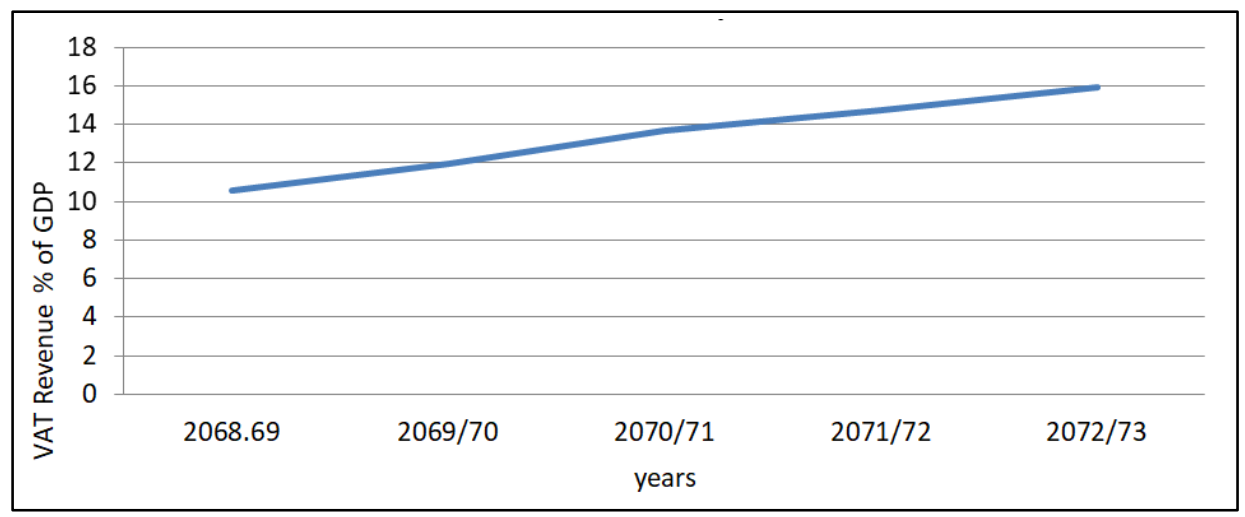

Figure 1: VAT percent on GDP

Sources: Economic Survey, (2068/69 to 2072/73), MOF

In above trend line shows the vat revenue percent on GDP. In fiscal year 2068/2069 VAT only contribute $10.58 \%$ on GDP. Similarly, in fiscal year 2069/2070, 2070/2071, $2071 / 2072$ and 2072/2073 VAT contribution on GDP are $11.95 \%, 13.00 \%, 14.72 \%$, and $15.94 \%$ respectively. However, though insignificantly, the percentage shows the increasing trend, but very low percentage of GDP throughout all the years of analysis.

\section{Conclusions}

The ultimate of the underdeveloped countries like Nepal is to achieve the economic development and ensure the rapid rate of economic growth. It needs huge amount of tax revenue in economic overheads and other development activities. VAT may be considered as basis tool in the path of economic development. VAT is one of the important and suitable means of raising government revenue. Contribution of VAT to GDP is not satisfactory.

The contribution of VAT to GDP in study period is not satisfactory. The contribution of VAT to GDP is only 10.58 percent in FY 2068/2069. The contribution of VAT to GDP is little increase to 15.94 percent in FY 2072/2073. In other word Nepalese VAT system is not efficient because various problems existed as increasing habit of tax evasion, defective VAT law, lack of experts in tax administration, lack of awareness of tax payers, etc.

The current Nepalese tax administration is not active and effective. Public awareness program is necessary for raising government revenue. Tax evasion is the major problem and 
there is a lengthy process while paying VAT. There is a possibility to make the current provision of fines and penalties reasonable by increasing them. Clear act, rules and regulation are most important factors for effectiveness of VAT in Nepal for raising government revenue. The role of VAT collection is very important in revenue mobilization of Nepal to meet the government expenditure and there is vital role to fulfill the resource gap problem of Nepal.

\section{Reference}

Basnet,B.B.(2014). Economic implication of foreign employment and inward remittance Business in Nepal, Unpublished Master's Thesis Central Department of Economics, T.U.

Jenkins, G. P. \& Khadka, R. (2000). Consulting Assistance on Economic Reform II Reform of Domestic Indirect Tax Systems in Low-Income Countries: The Case of Nepal. Harvard: Institute for International Development.

Jyoti, R. (2002). VAT: Analysis and Suggestion. Kathmandu: New Business Age.

Khadka, R. B. (2001). Value Added Tax, The Concept on International Experience and its application in Nepal. Kathmandu: IRD/ DANIDA.

Koirala, K. (2011). Value added tax (VAT) in Nepal: A critical assessment of its performance. The Journal of Nepalese Business Studies, VII (I); 63-69.

Mallik, B. (2003). Nepalese modern income tax system. Kathmandu: Anita Mallik Publication.

Ministry of Finance (2009/10 to 2016/17 ). Economic Survey. Government of Nepal.

Ministry of Finance (2009/10 to 2016/17). Annual Report Inland Revenue Department. Government of Nepal.

Neupane, D. R. (2008). A comparative Study on contribution of Direct Tax and Indirect Tax to National Revenue of Nepal, Kirtipur: MA Thesis, T.U.

Sharma, R. (2011). Contribution of VAT on Government Revenue in Nepal. M.B.S. Dissertation, Faculty of Management, T.U.

Shrestha, S. M. (2008). A Study on VAT: Implementation, Problems \& its Effectiveness in the Nepalese Economy. M.B.S. Dissertation, Faculty of Management, T.U.

Silwal, N. P. (2008). Value Added Tax: A Nepalese Experience. Kathmandu: Mrs. Indu Silwal.

Sutihar, D. N. (2016). Contribution of value added tax in Nepal. The Journal of Nepalese Business Studies, VIII (I); 53-59. 